\title{
Effect of Different Photoactivation Techniques on the Bond Strength of a Dental Composite
}

\author{
Eduardo DALL'MAGRO ${ }^{1}$ \\ Américo Bortolazzo CORRER ${ }^{1}$ \\ Ana Rosa COSTA ${ }^{1}$ \\ Gisele Maria CORRER ${ }^{3}$ \\ Rafael Leonardo Xediek CONSANI ${ }^{2}$ \\ Lourenço CORRER-SOBRINHO ${ }^{1}$ \\ Mário Alexandre Coelho SINHORETI ${ }^{1}$
}

\author{
${ }^{1}$ Department of Restorative Dentistry, Dental Materials Division, \\ Piracicaba Dental School, State University of Campinas, Piracicaba, SP, Brazil \\ ${ }^{2}$ Department of Prosthodontics and Periodontics, Prosthodontics Division, Piracicaba Dental School, \\ State University of Campinas, Piracicaba, SP, Brazil \\ ${ }^{3}$ Masters Program in Clinical Dentistry, Positivo University, Curitiba, PR, Brazil
}

\begin{abstract}
Using the push-out test, this study evaluated the bond strength of the composite resin Z250 (3M/ESPE) photoactivated with the XL2500

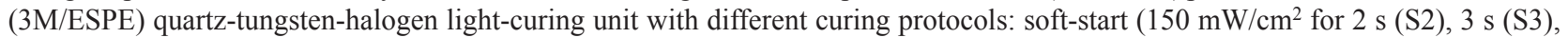
$5 \mathrm{~s}(\mathrm{~S} 5), 10 \mathrm{~s}(\mathrm{~S} 10)$ or $15 \mathrm{~s}(\mathrm{~S} 15)$, followed by $700 \mathrm{~mW} / \mathrm{cm}^{2}$ for $15 \mathrm{~s}$; pulse-delay $\left(150 \mathrm{~mW} / \mathrm{cm}^{2}\right.$ for $2 \mathrm{~s}(\mathrm{P} 2), 3 \mathrm{~s}$ (P3), $5 \mathrm{~s}$ (P5), $10 \mathrm{~s}$ (P10) or $15 \mathrm{~s}$ (P15), with a 1 -min delay, followed by $700 \mathrm{~mW} / \mathrm{cm}^{2}$ for $15 \mathrm{~s}$. After storage at $37^{\circ} \mathrm{C} \pm 1$ for $24 \mathrm{~h} \pm 1$, the specimens were ground, polished and subjected to a push-out test in a universal test machine (Instron) with a cell load of $500 \mathrm{~N}$ at a crosshead speed of $0.5 \mathrm{~mm} / \mathrm{min}$. The data were analyzed statistically by ANOVA and Tukey's test at $5 \%$ significance level. There were no statistically significant differences $(\mathrm{p}>0.05)$ among the groups photoactivated using the soft-start mode. For the pulse-delay mode, P5 promoted the highest bond strength $(\mathrm{p}<0.05)$. Groups photoactivated with the pulse-delay mode (except for P2 and P15) presented significantly higher bond strength than those photoactivated with the soft-start. It may be concluded that the influence of initial exposure time was curing method-dependent, with the best results obtained using the pulse-delay method with $5 \mathrm{~s}$ in the first photoactivation cycle.
\end{abstract}

Key Words: pulse-delay, soft-start, bond strength.

\section{INTRODUCTION}

The composite resins are the most used direct restorative materials in dentistry (1). However, the primary problem of dental composites is still the polymerization shrinkage. Shrinkage stress at the adhesive interface tends to destroy the bond between the composite resin and the tooth structure (2). The magnitude of shrinkage stress is due to polymerization reaction speed (3). The operator can minimize shrinkage stress and gap formation at interface during photoactivation using different photoactivation methods (4) or incremental techniques (5). To decrease the speed of the polymerization reaction, and consequently the shrinkage stress, techniques that suggest low irradiance during the initial period of photoactivation have been proposed (3-6). Soft-start polymerization technique adopts an initially low light intensity followed by a final cure with high light intensity. A slower rate of monomer-to-polymer conversion allows for better flow of the material, which, in turn, decreases contraction stresses, leading to better marginal adaptation $(6,7)$. Complementing photoactivation with high irradiance allows for composites achieving the maximum degree of conversion (6). In the pulse-delay photoactivation technique, there is a short period (about 1-3 min)

Correspondence: Prof. Dr. Mário Alexandre Coelho Sinhoreti and Prof. Dr. Lourenço Correr-Sobrinho, Faculdade de Odontologia de Piracicaba, UNICAMP, Área Materiais Dentários, Avenida Limeira, 901, 13414-903 Piracicaba, SP, Brasil. Tel: +55-19-2106-5348. Fax: +55-19-2106-5218. e-mail: sinhoret@fop.unicamp.brou sobrinho@fop.unicamp.br 
between initial exposition and final cure. This procedure can reduce the incidence of cavo-surface marginal gap and enamel fracture (8). Another advantage of these photoactivation methods is that the degree of cure is similar to conventional method (9).

However, there are still doubts as to the best photoactivation method and light exposure time to promote adequate bond strength between composite resins and dental structure. The aim of this study was to evaluate the bond strength of a composite resin photoactivated using soft-start and pulse-delay modes, with different initial light exposure times during the first photoactivation cycle.

\section{MATERIAL AND METHODS}

One hundred 3-mm-thick round metallic molds with a central cavity with $6 \mathrm{~mm}$ of lower diameter and $9 \mathrm{~mm}$ of the upper diameter were used (Fig. 1).

The molds were internally sandblasted with $40-\mu \mathrm{m}$ particle aluminum oxide using a micro-etcher (Danville Eng. Inc., San Ramon, CA, USA), and then etched with $37 \%$ phosphoric acid for $15 \mathrm{~s}$, water rinsed and dried. A bonding agent silane (Ceramic Primer; 3M ESPE, St. Paul, MN, USA) was applied and air dried for $5 \mathrm{~s}$. The adhesive system (Single Bond 2, 3M ESPE) was applied, air-thinned for $20 \mathrm{~s}$ and photoactivated for $10 \mathrm{~s}$.

A Mylar strip was positioned on a glass slab. The composite resin Z250 (3M ESPE; shade A3) was bulk inserted into the mold and another Mylar strip was seated onto the composite surface, and pressed manually using a microscope slide to remove composite excesses.

The composite resin was photoactivated with a quartz-tungsten-halogen light-curing unit (XL2500;3M ESPE) using soft-start and pulse-delay photoactivation methods (Table 1). The tip of the light guide of the curing units was moved away from composite resin surface to reduce irradiances, and acrylic resin (JET; Artigos Odontológicos Clássico, São Paulo, SP, Brazil) spacers were interposed between the composite surface and the tip of the curing units to standardize the photoactivation distance.

After photoactivation, the specimens were stored

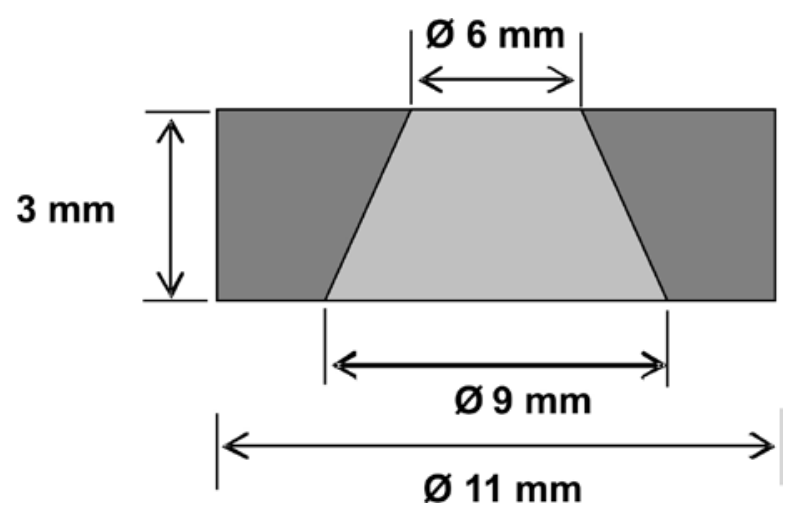

Figure 1. Schematic illustration of the metallic mold.

Table 1. Photoactivation methods.

\begin{tabular}{|c|c|c|c|c|c|c|c|}
\hline Method & Group & Time (s) & $\begin{array}{l}\text { Irradiance } \\
\left(\mathrm{mW} / \mathrm{cm}^{2}\right)\end{array}$ & Delay (min) & $\begin{array}{c}\text { Light } \\
\text { exposure (s) }\end{array}$ & $\begin{array}{l}\text { Irradiance } \\
\left(\mathrm{mW} / \mathrm{cm}^{2}\right)\end{array}$ & $\begin{array}{c}\text { Energy density } \\
\text { Total }\left(\mathrm{J} / \mathrm{cm}^{2}\right)\end{array}$ \\
\hline \multirow{5}{*}{ Pulse-delay } & $\mathrm{P} 2$ & 2 & 150 & 2 & 15 & 700 & 10.80 \\
\hline & P3 & 3 & 150 & 2 & 15 & 700 & 10.95 \\
\hline & P5 & 5 & 150 & 2 & 15 & 700 & 11.25 \\
\hline & P10 & 10 & 150 & 2 & 15 & 700 & 12.00 \\
\hline & P15 & 15 & 150 & 2 & 15 & 700 & 12.75 \\
\hline \multirow{5}{*}{ Soft-start } & $\mathrm{S} 2$ & 2 & 150 & --- & 15 & 700 & 10.80 \\
\hline & $\mathrm{S} 3$ & 3 & 150 & --- & 15 & 700 & 10.95 \\
\hline & S5 & 5 & 150 & --- & 15 & 700 & 11.25 \\
\hline & $\mathrm{S} 10$ & 10 & 150 & --- & 15 & 700 & 12.00 \\
\hline & $\mathrm{S} 15$ & 15 & 150 & --- & 15 & 700 & 12.75 \\
\hline
\end{tabular}


in incubator at $37^{\circ} \mathrm{C} \pm 1$ for $24 \mathrm{~h} \pm 1$, in a dark and dry container, before the push-out test. The top and bottom surfaces of restorations were ground using 400 grit sandpapers (Carborundum; Saint-Gobain Abrasivos Ltda, Cruz de Rebouças, Igaraçu, PE, Brazil) on an automated polisher under water cooling to remove the composite resin excess, promoting a correct positioning of specimens while testing.

For the push-out test an acrylic resin apparatus containing a central hole was attached in a universal testing machine (Instron Corp; Model 4411, Canton, MA, USA). A sphere-shaped rod attached to a compression load cell $(500 \mathrm{~N})$ was used to load the specimens until failure at a crosshead speed of $0.5 \mathrm{~mm} / \mathrm{min}$ (Fig. 2). The push-out bond strength was determined by computing the quotient of maximum load $(\mathrm{N})$ and adhesion area (equation for calculation of truncated cones, with values expressed in $\mathrm{mm}^{2}$ ). The data were analyzed statistically significant by two-way ANOVA (photoactivation mode and exposure time) followed by Tukey's test at the 5\% significance level.

\section{RESULTS}

Table 2 displays the mean and standard deviations for push-out bond strength. For pulsedelay photoactivation method group, P5 presented significantly higher bond strength than the other groups $(\mathrm{p}<0.05)$. Group P2 presented the lowest push-out bond strength, differing significantly $(\mathrm{p}<0.05)$ from P5 and

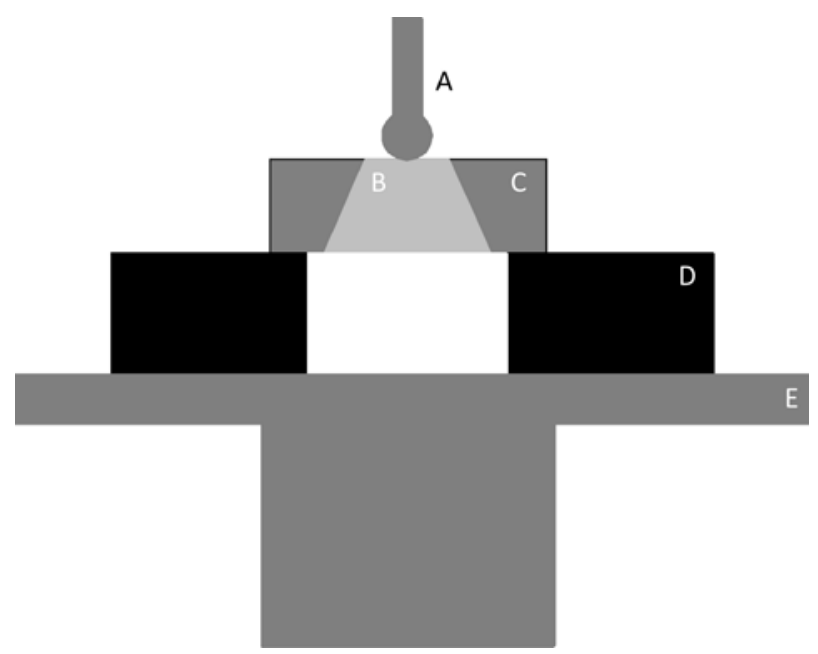

Figure 2. Schematic illustration of the metallic mold for push-out test. A: Sphere-shaped rod; B: Specimen; C: Metallic mold; D: Acrylic resin apparatus; E: Universal testing machine.
P10 groups. No statistically significant differences $(p>0.05)$ were found among groups photoactivated using soft-start methods. Comparison between photoactivation methods showed that P3, P5, and P10 presented significantly higher bond strength $(\mathrm{p}<0.05)$ than $\mathrm{S} 3$, $\mathrm{S} 5$, and S10, respectively. However, there were no significant differences between P2 and P15 compared to $\mathrm{S} 2$ and $\mathrm{S} 15$, respectively ( $\mathrm{p}>0.05)$.

\section{DISCUSSION}

During photoactivation, free radicals are generated to initiate the polymerization reaction of the composite resin. Both free radical generation and polymerization rate are influenced by the irradiance emitted from the light source (10). Photoactivation techniques that supply low irradiance during the initial period of photoactivation have been proposed to decrease polymerization rate and consequently the shrinkage stress (6). Thus, softstart and pulse-delay light modulation techniques were evaluated in this study.

The results showed that pulse-delay methods yielded significantly higher bond strength than soft-start mode. Both soft-start and pulse-delay method adopt an initial low irradiance followed by a final cure with high irradiance. However, the pulse-delay method adopt after the first polymerization cycle a period in "dark" (1 $\mathrm{min}$ ) before the second polymerization cycle. Pfeifer et al. (11) found a significant decrease on shrinkage stress (19\%) after 1 min delay, and attributed this results to either a lower degree of conversion or to a lower elastic modulus during the initial periods of polymerization. The reduction on the polymerization rate, and consequently in the stress rate could be related to improved marginal

Table 2. Push-out bond strength (MPa) means and standard deviations of Filtek Z250 composite resin photoactivated using different methods and exposure times.

\begin{tabular}{cccc}
\hline \multicolumn{2}{c}{ Pulse-delay (P) } & \multicolumn{2}{c}{ Soft-start (S) } \\
\hline P2 & $5.40(1.89) \mathrm{c}, \mathrm{A}$ & $\mathrm{S} 2$ & $4.16(0.78) \mathrm{a}, \mathrm{A}$ \\
P3 & $6.38(1.16) \mathrm{bc}, \mathrm{A}$ & $\mathrm{S} 3$ & $4.21(1.16) \mathrm{a}, \mathrm{B}$ \\
P5 & $34.20(8.47) \mathrm{a}, \mathrm{A}$ & $\mathrm{S} 5$ & $5.24(0.95) \mathrm{a}, \mathrm{B}$ \\
P10 & $7.80(2.33) \mathrm{b}, \mathrm{A}$ & $\mathrm{S} 10$ & $4.06(0.63) \mathrm{a}, \mathrm{B}$ \\
P15 & $6.12(1.73) \mathrm{bc}, \mathrm{A}$ & $\mathrm{S} 15$ & $5.26(1.19) \mathrm{a}, \mathrm{A}$ \\
\hline
\end{tabular}

Different lowercase letters in columns and uppercase letters in rows indicated statistically significant difference at $5 \%$. 
adaptation and bond strength. Cunha et al. (12) reported that the initial pulse limited the contraction force produced when the second, higher irradiance exposure was applied. Therefore, the maximum stress rate generated when stepped methods are used to photoactivate composite resin is reduced. This could lead to less gap formation and improved bond strength.

In the delay period, little amount of free radicals and double bonds conversion are produced and the composite resin has more time to molecular rearrangement and stress relief. The lower initial conversion may produce polymeric chains with greater mobility allowing more dark-cure and stress relief (13). Lim et al. (14) showed that a constant stress (1 MPa) was exerted by composites during the pause in the two-step curing routine. However, the slow rate of polymerization during the delay period may prolong the low modulus phase, without significant reduction in the degree of conversion (14).

For the soft-start method the activation of some free radicals during the first photoactivation cycle occurs and initiates the polymerization reaction. During the first polymerization cycle, the degree of conversion reaches about $50 \%$ of that obtained after the second light exposure. Immediately after the first polymerization cycle the specimens are photoactivated using the maximum irradiance emitted from the light source. The high irradiance after the first cycle does not allow that the stress be relief internally (15). Thus, the stress produced by fast polymerization reaction in the second polymerization cycle added to stresses produced in the first cycle are directed to bond interface, leading to gap formation and reducing the bond strength as compared to pulse-delay method (16).

When soft-start was used, the initial light exposure time did not influence the bond strength. However, specimens photoactivated with the pulse-delay method with short ( 2 and $3 \mathrm{~s}$ ) and long (10 and $15 \mathrm{~s}$ ) initial lightexposure times showed significantly lower bond strength than those photoactivated for $5 \mathrm{~s}$. These findings are in accordance with those of previous studies that used the pulse-delay method with different light exposure time to photoactivate composite resin (17). During the initial stages of polymerization reaction, contraction may be compensated for by flow within the material and contraction strain will produce contraction stress only after the development of a certain modulus of elasticity (about 50\%) (14). As the polymerization in the second cycle occurs at high speed, there is more shrinkage stress, leading to lower bond strength values (18).

The degree of conversion of composite resins depends on the energy density supplied during the photoactivation (19). P2 and P3 groups used 0.3 and 0.45 $\mathrm{J} / \mathrm{cm}^{2}$, respectively, in the first polymerization cycle. This amount of energy may have been insufficient to generate adequate amount of free radical and to polymerize adequately the composite resin during the first cycle. Thus, most of polymerization may have occurred in the second cycle that uses high irradiance, concentrating more stress at the bonding interface. The low energy density during the first cycle of polymerization may also explain the results found when comparing P2 and S2 groups, which showed no difference between them.

However, the groups that used longer initial light exposure times during the first photoactivation cycle (10 and $15 \mathrm{~s})$ also presented lower bond strength than P5 group. When composite resin is photoactivated with low irradiance a more linear polymeric chain can be formed. Materials with linear polymer chains are more susceptible to the effects of plasticizers, reducing the resistance values. Moreover, P10 and P15 were photoactivated with the highest energy densities (12 and $12.75 \mathrm{~J} / \mathrm{cm}^{2}$, respectively). Previous studies reported that the higher the density of energy supplied during light curing, the greater the degree of conversion and polymerization shrinkage (20). Therefore, more stress can be directed to the bonding interface, leading to a reduction on the bond strength. Besides, the increase of photoactivation time (P15 and S15) leads to a rapid increase on elastic modulus, reducing the composite resin flow. Therefore, stresses cannot be released into the material, leading to a possible rupture of the resindentin bond, even if a delay period is used after the first curing cycle. Prolonged curing time can reduce the bond strength of restorations, even when modulated photoactivation methods are used.

The results showed that great differences between P5 and the others groups were found. These results could be associated to absence or reduction on gaps formation between the composite resin and the metallic mold. Gaps are sites of stress concentration and are associated with an accentuated decrease in bond strength (P2, P3, P10, and $\mathrm{P} 15$ groups). However, the absence or reduction of the gaps allows tension to be distributed across the bond interface, increasing the bond strength (P5 group).

Within the limitations of this study, it may be concluded that the exposure time during the first photoactivation cycle affected the bond strength of 
the pulse-delay method, with the highest results for P5 (5 s light exposure time). However, soft-start was not influenced by the exposure time variations. The pulse-delay method was proven more effective than the soft-start method.

\section{RESUMO}

O objetivo deste estudo foi avaliar a resistência de união (push-out) da resina composta Filtek Z250 (3M/ESPE), fotoativada com luz de lâmpada halógena XL2500 (3M/ESPE), utilizando diferentes protocolos de fotoativação: soft-start $\left(150 \mathrm{~mW} / \mathrm{cm}^{2}\right.$ por 2 (S2), 3 (S3), 5 (S5), 10 (S10) ou $15 \mathrm{~s}(\mathrm{~S} 15)$, seguido por $700 \mathrm{~mW} / \mathrm{cm}^{2}$ por $15 \mathrm{~s}$; e pulse-delay $\left(150 \mathrm{~mW} / \mathrm{cm}^{2}\right.$ por 2 (P2), 3 (P3), 5 (P5), 10 (P10) ou $15 \mathrm{~s} \mathrm{(P15),} \mathrm{com} 1 \mathrm{~min}$ de espera, seguido de $700 \mathrm{~mW} /$ $\mathrm{cm}^{2}$ por $15 \mathrm{~s}$. As amostras foram armazenadas a $37^{\circ} \mathrm{C} \pm 1$ por 24 $\mathrm{h} \pm 1$, lixadas, polidas e submetidas ao ensaio de resistência de união (push-out) em máquina de ensaio universal (Instron) com velocidade de $0,5 \mathrm{~mm} / \mathrm{min}$. Os dados foram submetidos à Análise de Variância e teste de Tukey (5\%). Os resultados mostraram que não houve diferença significativa entre os grupos fotoativados pelo método soft-start ( $\mathrm{p}>0,05)$. Para o método pulse-delay, o grupo P5 apresentou a maior resistência de união, significativamente superior aos outros grupos. Os grupos fotoativados pelo método pulse-delay (exceto P2 e P15) apresentaram resistência de união significativamente superior ao método soft-start. Pode-se concluir que a influência do tempo de exposição inicial foi métododependente, sendo os melhores resultados apresentados pelo método pulse-delay fotoativado com exposição inicial de $5 \mathrm{~s}$.

\section{REFERENCES}

1. Rueggeberg FA, Craig RG. Correlation of parameters used to estimate monomer conversion in a photoactivated composite. J Dent Res 1988;67:932-937.

2. Lindberg A, van Dijken JW, Horstedt P. Interfacial adaptation of a Class II polyacid-modified resin composite/resin composite laminate restoration in vivo. Acta Odontol Scand 2000;58:77-84.

3. Koran P, Kurschner R. Effect of sequential versus continuous irradiation of a photoactivated resin composite on shrinkage, viscosity, adhesion, and degree of polymerization. Am J Dent 1998;11:17-22.

4. Obici AC, Sinhoreti MA, de Goes MF, Consani S, Sobrinho LC. Effect of the photoactivation method on polymerization shrinkage of restorative composites. Oper Dent 2002;27:192-198.

5. Tjan AH, Bergh BH, Lidner C. Effect of various incremental techniques on the marginal adaptation of class II composite resin restorations. J Prosthet Dent 1992;67:62-66.

6. Watts DC, al Hindi A. Intrinsic 'soft-start' polymerisation shrinkage-kinetics in an acrylate-based resin-composite. Dent Mater 1999;15:39-45.
7. Uno S, Asmussen E. Marginal adaptation of a restorative resin polymerized at reduced rate. Scand J Dent Res 1991;99:440-444.

8. Kanca $\mathrm{J} 3^{\text {rd }}$, Suh BI. Pulse activation: reducing resin-based composite contraction stresses at the enamel cavosurface margins. Am J Dent 1999;12:107-112.

9. Obici AC, Sinhoreti MAC, Frollini E, Sobrinho LC, Consani S. Degree of conversion and knoop hardness of Z250 composite using different photoactivation methods. Polymer Testing 2005;24:814-818.

10. Lovell LG, Newman SM, Bowman CN. The effects of light intensity, temperature, and comonomer composition on the polymerization behavior of dimethacrylate dental resins. J Dent Res 1999;78:1469-1476.

11. Pfeifer CS, Braga RR, Ferracane JL. Pulse-delay curing: influence of initial irradiance and delay time on shrinkage stress and microhardness of restorative composites. Oper Dent 2006;31:610615.

12. Cunha LG, Alonso RC, Pfeifer CS, Correr-Sobrinho L, Ferracane JL, Sinhoreti MA. Contraction stress and physical properties development of a resin-based composite irradiated using modulated curing methods at two C-factor levels. Dent Mater 2008;24:392-398.

13. Lovell LG, Newman SM, Donaldson MM, Bowman CN. The effect of light intensity on double bond conversion and flexural strength of a model, unfilled dental resin. Dent Mater 2003;19:458-465.

14. Lim BS, Ferracane JL, Sakaguchi RL, Condon JR. Reduction of polymerization contraction stress for dental composites by twostep light-activation. Dent Mater 2002;18:436-444.

15. Sakaguchi RL, Wiltbank BD, Murchison CF. Contraction force rate of polymer composites is linearly correlated with irradiance. Dent Mater 2004;20:402-407.

16. Dall'Magro E, Sinhoreti MA, Correr AB, Correr-Sobrinho L, Consani S, Puppin-Rontani RM. Effect of different initial light intensity by the soft-start photoactivation on the bond strength and Knoop hardness of a dental composite. Braz Dent J 2007;18:107112.

17. Dall'Magro E, Sinhoreti MA, Correr AB, Consani RL, Sicoli EA, Mendonça MJ, et al.. Effect of different modes of light modulation on the bond strength and knoop hardness of a dental composite. Braz Dent J 2008;19:334-340.

18. Silikas N, Eliades G, Watts DC. Light intensity effects on resincomposite degree of conversion and shrinkage strain. Dent Mater 2000;16:292-296.

19. Correr AB, Sinhoreti MA, Sobrinho LC, Tango RN, Schneider LF, Consani S. Effect of the increase of energy density on Knoop hardness of dental composites photoactivated by conventional QTH, LED and xenon plasma arc. Braz Dent J 2005;16:218-224.

20. Dewaele M, Asmussen E, Peutzfeldt A, Munksgaard EC, Benetti $A R$, Finne $G$, et al.. Influence of curing protocol on selected properties of light-curing polymers: degree of conversion, volume contraction, elastic modulus, and glass transition temperature. Dent Mater 2009;25:1576-1584.

Accepted June 22, 2010 